\title{
Reseña.
}

\section{The Lighthouse: mares tenebrosos}

The Lighthouse: Dark Seas

\author{
Miguel Ángel Vidaurre Ferrada ${ }^{1}$ \\ UNIVERSIDAD ACADEMIA HUMANISMO CRISTIANO
}

Título original: The Lighthouse. Dirección: Robert Eggers. Guion: Robert Eggers, Max Eggers. Fotografía: Jarin Blaschke. Diseño de producción: Craig Lathrop. Montaje: Louise Ford. Música: Mark Korven. Reparto: Willem Dafoe, Robert Pattinson. Año: 2019. País: Estados Unidos. Duración: 110 min.

El sonido de la sirena llega entonces, y se va, y llega y se va otra vez, y te mueves en el barroso fondo de los abismos, y abres los ojos como los lentes de una cámara de cincuenta milímetros, y te mueves lentamente, lentamente, pues tienes todo el peso del océano sobre los hombros.

(La sirena. Ray Bradbury)

\section{1}

La niebla, el océano monstruoso que golpea la quilla, la silueta grisácea de un faro en el horizonte, dos hombres parados en la proa de un barco, de espaldas a nosotros, como en muchas pinturas románticas, y a lo lejos el sonido ominoso de la sirena de un faro.

Parece una imagen de un mundo perdido, un tiempo extraviado en el imaginario del océano sublime y terrible de fin del siglo XIX. Un dibujo al carboncillo de Van Gogh, una xilografía de Doré. Emerge la isla, el faro y las imágenes resuenan a Bocklin y su Isla de los muertos, más adelante sus imágenes perversas y erotizadas de tritones y sirenas, tendrán aún más espesura en el filme.

Los dos hombres bajan a la isla, caminan por un desfiladero observando con reverencia el océano. La sirena vuelve a lanzar su gemido, y resonará a lo largo de todo el filme como una señal de alarma para otros que se acerquen a esta isla, o como un animal moribundo como en el cuento de Bradbury.

En un momento, ambos personajes se detienen, miran al lente lateralmente, y la sirena vuelve a resonar, mientras que el contraplano nos muestra como el barco se esfuma en la niebla. Ya están solos, estos vástagos del horror marítimo, víctimas de las aguas negras, de las gaviotas vengativas de Hitchcock, entremezcladas con el Viejo marinero de Coleridge. Esas miradas siniestras al lente, parece dialogar con otro filme monstruoso, que demoró varios años en culminar y que se asemeja en la textura oscura y su densidad de grabado al filme de Eggers: Qué difícil es ser un dios (Trydno byt bogom. 2014) del cineasta ruso Aleksei German. Filme de ciencia ficción, que, sin embargo, opera como un viaje en el tiempo, cuando un grupo de astronautas provenientes de la tierra aterrizan en un planeta enmarcado en una edad media que parece sacada de grabados medievales y de pinturas de Pieter Brueghel llamado el Viejo.

\footnotetext{
${ }^{1}$ Licenciado en Estética, Pontificia Universidad Católica de Chile. Magíster (c) en Historia y Teoría del Arte en la Universidad Chile. Doctor (c) en Educación, Universidad Academia de Humanismo Cristiano. Mail: mvidaurre@academia.cl
} 
2

Mark Korven, el compositor de la banda sonora de The Lighthouse se asoció con el fabricante de guitarra Tony Duggan-Smith para elaborar un instrumento original que ayudaría en la fabricación de sonidos tenebrosos. "“Un instrumento normal, lo estás tocando y esperando que tenga un sonido que sea agradable", pero con un instrumento como este, el objetivo es producir sonidos, que, en este caso, son inquietantes" el resultado fue una maquina tan extraña y de apariencia arcaica como el mismo filme de Robert Eggers: El The Apprehension Engine un aparato híbrido que según Korven fuera capaz de producir la sensación de fuerzas elementales.

El The Apprehension Engine, es una máquina diabólica, construida para producir resonancias que convoquen la inquietud en los oyentes y carguen de extrañeza las imágenes del filme. Dispositivo herético que convoca el fantasma del Tritono: Diabolus in Música, esa disonancia siniestra que rompía con el ideal de lo perfecto y lo divino en el medioevo.

Según Korven, Robert Eggert quería algo muy elemental, primario, por lo que la banda sonora estuvo concebida como una serie de elementos que sirviesen para envolver a estos dos tipos luchando por no caer en la desesperación y la locura. Había que expresar musicalmente los sonidos del viento, las olas chocando, las gaviotas... una especie de representación de todo lo relacionado con el mar.

Lo elemental, lo primario. El tono xilográfico de la fotografía en blanco y negro, la relación de formato 1:19:1, que le da el aspecto de contemplar un objeto de la década de los 20, un filme de Dreyer como Vampyr (1932), o la versión de Jean Epstein de Poe en La caída de la casa Usher (La Chute de la maison Usher. 1928) cuando lo fantasmagórico era un asunto de texturas y materialidad más que de argumentos narrativos.

3

Los dos hombres están encerrados en la isla. Capturados en un edificio que se levanta como una torre vertical, donde se instala la luz del faro, y que hunde sus raíces en la profundidad oscura de la tierra, en donde se encuentran las calderas y las máquinas que mantienen viva esa luz. Thomas Wake (William Defoe) es el viejo marino, experimentado y ebrio que habita la inquietante torre, y su ayudante Ephraim Winslow (Robert Pattinson) el introvertido hombre de los bosques canadienses, se sumerge en la tierra, la lluvia y el carbón, con la permanente prohibición de ascender a la luz y a la sirena. La prohibición es fundamental para lo fantástico. La torre de luz, oculta lo indescriptible, lo inmostrable. Wake es su guardián y amante. Winslow carga con su propia oscuridad traída desde otras zonas antiguas, los bosques y los ríos. Ambos son seres de las materias fundamentales.

La atmosfera lo carga todo de una sensación parecida al horror, o quizás a una permanente tensión que se desplaza desde la locura a la literalidad de lo fantástico. La sirena del faro, el viento, los gritos de las gaviotas, el rumor del mar, se hacen partícipe en un contexto que resuena previo al cristianismo, o de espaldas a él. Son tierras paganas, emociones incontrolables, discursos heréticos que no son dichos sino bramados por hombres que parecen extraídos del imaginario de William Blake, o de la cólera demoniaca del Ahab de Melville.

Una escena pequeña e inquietante: Winslow se sienta en su sucio camastro, siente algo incómodo al interior del delgado colchón, introduce sus dedos por un agujero y extrae una enigmática figura de una sirena. La acaricia y la oculta. Parece una escena de un filme de Jacques Tourneur, como si se tratase de un fragmento no filmado de Cat People (1942) o Night of the Demon (1957), en donde lo pequeño es más siniestro que lo espectacular. El inicio del filme con los hombres en el barco, parece ser otro punto de contacto con Tourneur, en este caso con I Walked 
with a Zombie (1943). Las sensibilidades paganas se atraen, y rechazan las fáciles soluciones cristianas.

4

"Y entonces, con un chapoteo sordo y aterrador, un ser marino emergió un poco más allá de la línea de las olas" (La noche del océano. Robert Barlow \& H:P: Lovecraft)

El océano, de lo sublime a lo aterrador. Las aguas oscuras, ciénagas, sargazos. La inversión simbólica de la aventura, la libertad y la puesta de sol. Una sensibilidad profunda y trágica une a los escritores anglosajones en torno a los mares tenebrosos que los rodean. El espacio interior.

Desde Poe y su Maelstrom, y su Gordon Pym extraviado en la inmensidad de la blancura demoniaca, hasta Lovecraft y su imaginario de criaturas indescriptibles e infilmables, toda bestia lovecraftiana se vuelve ridícula en su exhibición, en su efecto especial que traiciona su profunda naturaleza anticultural. No hay palabras que sirvan para describirlas a cabalidad, no hay imágenes que soporten su otredad.

The Lighthouse parece ligarse a esta sensibilidad herida por lo insondable del océano. Un paso más allá de la distancia sublime ante la tormenta de Turner o Friedrich, estos autores contaminan nuestra contemplación de lo marino con la vastedad del horror cósmico.

William Hope Hodgson, es uno de los maestros de este estilo. Sus marinos son hombres curtidos a la vez que aterrados. Heroicos pero destrozados espiritualmente, psíquicamente, eróticamente. Lo conocido en tierra deja de operar al interior del buque, del faro, de la isla. Los ordenamientos, los manuales, la burocracia cesan de funcionar, y un profundo sentimiento los invade: el horror, el extravió, la locura.

\section{5}

Thomas Wake y Ephraim Winslow están acabados. Un aire recorre la isla, semejante a ese viento enfermizo de esas maravillas de cine fantástico moderno que Bergman filmo en un lugar de nombre premonitorio: Faro. Léase una posible conexión, quizás imposible, entre Vargtimmen, y The Lighthouse.

La ebriedad, la tormenta y una atmosfera propicia para la violación, el crimen y la transfiguración mental dominan el último tercio del filme.

La muerte a golpes de la gaviota por parte de Winslow parece recitar el verso de Samuel Coleridge: “¿Por qué miras así? Con mi ballesta. Yo maté al Albatros”. Sus visiones entremezcladas de lo que puede ser un crimen o un accidente, la sirena que lo atrae y devora, la ansiedad que lo corroe de ascender al lugar de Wake.

Citando la pintura Hipnosis del pintor simbolista Sascha Schneider, Wake sujeta el brazo de Winslow y lo posee a través de la luz del faro que emana desde sus ojos. Un tentáculo de textura lovecraftiana parece arrastrarse por la superficie la torre. Cuando estalla la locura, la tormenta revienta y la sonoridad de la sirena y del The Apprehension Engine ocupan todo el espacio sonoro del filme ingresamos al espacio del horror cósmico, donde el lenguaje cede al cuerpo, donde la razón debe enfrentar lo que escapa a su capacidad, solo resta hundirse, dejarse llevar, hundirse en las aguas y ser absorbido.

\section{Filmografía}

The Lighthouse. Dir. Robert Eggers. 2019. 